\title{
PUBLIC INTEREST IN TAXATION OF PROFESSIONAL SPORTSMEN IN THE CZECH REPUBLIC ${ }^{1}$
}

\author{
ROMAN VYBÍRAL ${ }^{2}$
}

\begin{abstract}
This contribution discusses the development of case law relating to the taxation of income from professional sportsmen in the area of collective sports in the Czech Republic. The Supreme Administrative Court has, over time, published a number of controversial decisions, which, instead of clarifying and unifying the existing practice, brought new issues into this area, and it should be pointed out that these are often rather controversial and a question arises whether conclusions arising from those decisions are in public interest.
\end{abstract}

\section{Keywords}

Sport; professional sportsman; income tax; Supreme Administrative Court

JEL Classification: H24, K34, Z23

\section{Introduction}

The field of professional sport has undergone in recent years a very interesting development, which led to the absolute loosening of the rules for taxation of income of professional sportsmen. As a result of this development, the choice of the tax regime is now in the hands of athletes, resp. sports clubs. Currently, there are three basic income tax regimes where athletes can act as employees, as persons running independent profession or as persons carrying on a trade.

1 This paper has been elaborated within the programme "PROGRES Q02 - Publicization of Law in the European and International Context" which is realized in 2018 at the Faculty of Law of the Charles University.

2 Assistant Professor of Financial Law and Financial Science, Department of Financial Law and Financial Science, Faculty of Law, Charles University, Czech Republic. The Author specializes in tax law and insurance law. He is the author or co-author of more than 30 reviewed articles and books. He is a member of Information and Organization Centre for the Research on the Public Finances and Tax Law in the Countries of Central and Eastern Europe. Orcid.org/0000-0002-1112-408X. Contact email: vybiralr@prf.cuni.cz. 
This consequently leads to the fulfilment of the proverb duo cum faciunt idem idem non est. It has to be said that the field of professional sport shows signs of deliberate misinterpretation of the text of the legal norm in order to choose a more advantageous legal regime by the contractual parties. This thesis is directly linked to the concept of tax evasion largo sensu (Almendral, 2005: 560 et seq.).

The main purpose of this contribution is to analyse the relevant case law concerning the status of professional sportsmen in the field of individual income tax, to highlight the fundamental lacks of the individual decisions and, last but not least, to assess whether this case law is in the right course and whether it is in line with the public interest represented here by the interest in the proper taxation of the income of professional sportsmen. The contribution is mainly based on the text of legislation, case law, and research publications.

\section{Triple Standards for Sportsmen}

Dichotomy (nowadays rather trichotomy) in perception of the same conduct or behaviour is not only discouraging for the addresses of legal norms to trust in a uniform and compact legal system, but at the same time such a contradictory situation infringes the principles of legal certainty and foreseeability of law (Constitutional Court: I. ÚS 420/09). In addition, it degrades, vulgarly said, legal norms as a whole to a lower level. Naturally, the law cannot be utterly perfect and indisputable, but if it goes so far that the legal gaps are artificially created, moreover when that happens under the guise of court decisions of the highest judicial instances in the country, the situation is rather alarming.

This very brief and theoretically focused passage stems from the current practice and, if nothing changes, it is expected to be future practice as well, in the area of collective sports when players perform the exact identical activity, yet their tax regime may be divided into more (specifically three) categories. The primary cause of this is the case law, although it is also possible to talk about a few minor mistakes made by the legislator. In the Czech Republic we are still in a space-time where court decisions are not formally binding, however, it is not possible to deny them certain material binding effect, especially if they are so-called constant. In the decision of Supreme Administrative Court of 13 July 2017, no. 6 Afs 278/2016, which will be further analyzed in this text, just a single judgment was enough to make the case law "constant". Apparently, in order to speed up the process of creating constant case law, which would probably, in the current case law of the Supreme Administrative Court regarding taxes, just delay the inevitable conclusion. 
Financial Administration changed its previous practice on the basis of a single decision, when it stated in its opinion of 27 July 2017 that "(...) on the basis of this judgment it adapts its administrative practice of taxation of professional sportsmen, particularly in so-called "collective" sports (football, hockey, handball, etc.), i.e. it will be based on the fact that the activity of a professional sportsman can be performed pursuant to Sec. 7 of the Income Taxes Act, either as a trade, on the basis of the relevant trade license, when the income from this activity represents income from the trade according to Sec. 7 subsection 1 paragraph b) of the Income Taxes Act (...)" (Financnisprava.cz). In other words, the Financial Administration expressly admits the double regime in the taxation of these sportsmen' income.

The question whether a sportsman can officially play for a club also formally in the position of a dependent person seems to be resolved (Morávek, Štefko, 2013: 354 et seq.). In its earlier decision of 29 November 2011, no. 2 Afs 16/2011, the Supreme Administrative Court addressed this issue quite ambivalently, when it de facto stated that due to the inappropriately chosen terminology of the relevant legal regulation, it is up to the contracting parties, i.e. sportsmen and clubs, which regime of taxation they are going to choose. Nevertheless, such approach can only succeed if the legislation is truly unclear. Even if the legislation explicitly provides the choice of several regimes, it is always essential to examine the material nature of the activity in question, not just the formal fulfillment of certain parameters. In other words, if the legislation states that an object may be "green" or "blue", then logically there should not be a situation when the object is materially "blue", but outwardly appears as "green". There is an a priori question whether the case law of the Supreme Administrative Court analyzed below is not in stark contrast to the mentioned principle. Moreover, if this case law reaches a conclusion that the object may be de facto also "red".

\section{Case Law Defining the Dependent Activity}

In the next two chapters, the key decisions of the Supreme Administrative Court will be analyzed. These decisions in their entirety currently create the framework in which sportsmen operate. As indicated in the previous paragraphs, professional sportsmen in the area of collective sports and their clubs have in principle three options how to arrange the internal organization of their relationship, including the tax regime.

I will first mention the judgment of the Supreme Administrative Court of 1 June 2005, no. 2 Afs 176/2004, in which the court dealt with the characteristics common to the employment, service and member relationship. The reason was (and for that matter still is) the diction of the provision of Sec. 6 Subsec 1 par. a) of 
Act no. 586/1992 Coll., on Income Taxes, as amended, which, when determining the so-called dependent activity, also counts with relationships similar to those mentioned above in cases when the taxpayer is obliged to obey the player's orders. Specifically in this context the court states that "this legal relationship arises between the subjects to which it relates, most often on the basis of a bilateral legal act (typically employment contracts), that is to say the same expression of will of the contracting parties (...) it is necessary to always consider its real, by the parties intended and wanted content of the relationship, and not just the outside (...)." This is a manifestation of the principle of material truth, which is nowadays quite standard in the field of tax law.

As another important feature of employment, service and member relationship, the court states that "this relationship is established as a relationship of a lasting nature characterized by the fact that it is not consumed on a one-time basis (...)." At the same time, the court adds that "another significant characteristic of employment, service, and member relationship is that the person, who is providing some specific performance (i.e. in the above-mentioned relationships, certain work activity) is essentially obliged to follow the instructions of the employer or superior. This obligation must be directly established, i.e. as the subject matter of the legal relationship between the two parties."

The Supreme Administrative Court has moved further in this context in its earlier judgment of 31 March 2004, no. 5 Afs 22/2003. The court already clearly distinguishes the term "dependent activity" according to the Income Taxes Act from "dependent labor" under the Labour Code. To this, the court states that "the term dependent activity used in the Income Taxes Act is not identical with the labor law term of dependent labor (hiring labor force for remuneration). The legal relationship from which the income is generated is not decisive for the qualification of income subjected to the provision of Sec. 6 of Act no. 586/1992 Coll. for the purposes of income taxation. The substantial characteristic of dependent activity is the fact that it is not carried out independently, i.e. in one's own name, on one's own account, and on taxpayer's own responsibility, but on the contrary following the instructions of the person, who pays the remuneration for the work provided (the payer)".

The court further discusses the individual characteristics of the dependent activity such as dependence, consideration, economic mutuality etc. (Sluka, 2007: 69 et seq.). The very important conclusion of the court is that "the above-described characteristics must be met simultaneously in a relationship that is supposed to be analogous to the employment, service and member relationship; when just one of the characteristics is absent to a substantial extent in a given relationship, it cannot be considered as analogous to the employment, service and member relationship". It is 
absolutely crucial to use the concept of meeting all the characteristics, although not always to a full extent. The court expressly states that one (or more) characteristics can be overshadowed, but not to a substantial extent (Vybíral, 2013: 12 et seq.).

\section{Case Law Concerning Professional Sportsmen}

I consider the conclusion of the Supreme Administrative Court mentioned in the previous paragraph to be very significant also with regard to the discrepancy between this conclusion and the subsequent case law of the court when the court expressly relativizes the conclusion so that it would achieve the apparently intended goal in its decisions. This turnover in the court opinion is evident especially in the judgment of 29 November 2011, no. 2 Afs 16/2011 and in the judgment of 13 July 2017, no. 6 Afs 278/2016. In both of the mentioned decisions, the court reaches the conclusion that the legal regulation of the status of professional sportsmen is not enshrined uniformly in the Czech Republic and applying the principles of in dubio mitius and in dubiis contra fiscum it is up to the subjects of taxation to decide, which taxation regime is more suitable for them.

In case of the first mentioned decision of the Supreme Administrative Court of 29 November 2011, no. 2 Afs 16/2011, it is necessary to highlight two disputable points. The first disputable point is the statement of the court that "it is obvious that the activity of sportsmen is very close to the conceptual definition of dependent activity, nevertheless it does not achieve its intensity." However, the court did not evaluate the individual aspects of the activity of sportsmen thoroughly enough to establish the degree of intensity. At the same time, it might be that the court did not have in mind the term "dependent activity", but more likely, the term "dependent labor", since it did not refer to any of its previous case law concerning dependent activity. This conclusion is also supported by the statement of the court following the above-mentioned excerpt from the judgment, where the court states that "(a) partial conclusion can be reached that the activity of professional sportsmen is not easily subsumable under the term "dependent labor" pursuant to the Labour Act". I could not agree more with this conclusion, however, the court still does not address the issue of dependent activity, or rather the extent of absence to which the individual characteristics are not met. Therefore, I consider the above-mentioned judgment full of gaps and in many aspects in contradiction with previous case law.

The most current decision of the Supreme Administrative Court in the field of taxation of professional sportsmen' income is the judgment of 13 July 2017, no. 6 Afs $278 / 2016$. This judgment can be perceived as greatly controversial and perhaps even rather absurd. In this judgment, the court is not at all considering the key issue whether the sportsmen in the area of collective sports meet the individual 
characteristics of dependent activity established by the court's previous case law, but is rather concerned with the question whether the status of these sportsmen can be considered a trade. Instead of stabilizing the situation in the area of professional sports in the past twenty years or so, the Supreme Administrative Court allowed for the relevant opening of completely new category primarily by using very problematic and wholly substitutable arguments.

After the court had considered the individual characteristics of trade, it reached quite a Solomonic conclusion when it states that "in the case of a professional football player the individual characteristics of trade are not met in their pure form. However, the legal regulation clearly states that the content of the trading activity operation of sports facilities and organization of sports activities also includes the activity of performing sportsmen carried out independently for profit". It is as if the court indicated by this conclusion that meeting the characteristics of trade is de facto not necessary and it is enough that some activity is close to these characteristics. Moreover, the court preferred form to content when it stated that "in this context, it is important to mention that the respective Trade Licensing Office has in fact issued the authorization to the trade activity Operation of sports facilities and organization of sports activities". Nevertheless, given the scope of this trade activity, we cannot automatically assume that it would also, without further ado, include the performance of sports activity.

The Supreme Administrative Court mentions a wide variety of other arguments that cannot be closely analyzed given the extent of this article. Materially speaking it is quite clear that in this judgment the court gave its blessing to the existence of the so-called "švarcsystém" (i.e. misclassification of employees as independent contractors) in the area of collective sports and took the issue of professional sportsmen' taxation to a different, entirely absurd level.

\section{Conclusions}

I am convinced that the case law analyzed instead of solving the controversial situation in the field of professional sport has brought new controversial issues. The fact that athletes and clubs will be able to choose the tax regime that is the most advantageous for them is undoubtedly not in line with the public interest.

It is only a matter of time when the Czech Republic will incline to the practice of all developed European countries and it will legally explicitly lay down the status of professional sportsmen, for example, in a special legal regulation. The second option is that the Czech Republic will still remain at the level of developing countries and 
the approval of the so-called "švarcsystém" in the field of the sport by the Supreme Administrative Court will expand into wider spheres of human activity.

\section{References}

Almendral, V.R.: Tax Avoidance and the European Court of Justice: What is at Stake for European General Anti-Avoidance Rules, INTERTAX no. 12 (2005).

Gábriš, T.: Športové právo (Sports Law), Bratislava: Eurokódex, 2011.

Križan, L.: Mal by mat' profesionálny futbalista na Slovensku postavenie zamestnanca? (Should be a professioal sportsman an employee in Slovakia?), Bulletin slovenskej advokácie (Bulletin of Slovak Advocacy) no. 3 (2009).

Morávek, J., Štefko, M.: Profesionální sportovec v kolektivních sportech (Professional sportsman in collective sports), Časopis pro právní vědu a praxi (Journal for Legal Science and Practice) no. 3 (2013).

Sluka, T.: Profesionální sportovec: právní a ekonomické aspekty (Professional Sportsman: Legal and Economic Aspects), Praha: Havlíček Brain Team, 2007.

Vybíral, R.: Analýza judikatury vztahující se $\mathrm{k}$ postavení profesionálních sportovců $\mathrm{v}$ oblasti kolektivních sportů v České republice (Analysis of case law concerning the status of professional sportsmen in the field of collective sports), Jurisprudence no. 1 (2013).

Sdělení GFŘ k rozsudku NSS ve věci zdaňování příjmů profesionálních sportovců (Opinion of the GFǨ to the Judgement of the Supreme Administrative Court about taxation of professional sportsmen), 2017. www.financnisprava.cz.

CZ: Act no. 586/1992 Coll., on Income Taxes, as amended.

CZ: Act no. 262/2006 Coll., the Labour Code, as amended.

CZ: Constitutional Court: I. ÚS 420/09.

CZ: Supreme Administrative Court: 5 Afs 22/2003.

CZ: Supreme Administrative Court: 2 Afs 176/2004.

CZ: Supreme Administrative Court: 2 Afs 16/2011.

CZ: Supreme Administrative Court: 6 Afs 278/2016. 